\title{
Ima miselnost o nespremenljivosti inteligentnosti učinek v neustrezni bralni samopodobi?
}

\author{
Marjan Šimenc, Pedagoška fakulteta Univerze v Ljubljani \\ Mojca Štraus, Ministrstvo za izobraževanje, znanost in šport
}

a uspeh se je treba potruditi, « je navodilo, ki ga starši pogosto
ponujajo svojim otrokom in učitelji svojim učencem, ko le-ti
naletijo na učne težave. Vendar se zdi, da to navodilo otroci in učenci pogosto preslišijo. Ali pa ga razumejo narobe? Nekateri se le vržejo $\mathrm{v}$ ponavljanje istega, do sedaj neuspešnega, pristopa $\mathrm{k}$ učenju, za nekatere druge pa se zdi, da so obupali, ker tako ali tako ne morejo nič.

Magajna in sodelavci navajajo, da je problem šolske neuspešnosti kompleksen in trdovraten ter ima različne pojavne oblike (Magajna et al., 2008: str. 15). Tipi težav se ločijo glede na primarne vzroke v okolju in/ali posamezniku (ibid.: str. 16). O posledicah nerazrešenih učnih težav pa pravijo: »Razširjen in trdovraten problem učnih težav in šolske neuspešnosti ima torej daljnosežne posledice, tako za posameznikovo funkcioniranje in kakovost življenja kot tudi za funkcioniranje širše družbe z vidika razvoja človeških virov, konkurenčnosti in socialne kohezivnosti.« (ibid.: str. 20).

V raziskavah so ugotovili (npr. Dweck, 2007), da se učne težave povezujejo z vprašanjem prepričanj oziroma miselnosti o (ne)spremenljivosti inteligentnosti in posledicah teh prepričanj za učno uspešnost. Ameriška zveza psihologov (American Psychological Association) je prepoznavo, da prepričanja učencev o inteligentnosti in sposobnostih vplivajo na njihove spoznavne procese in učenje, uvrstila kot prvo med dvajset najpomembnejših psiholoških načel za poučevanje in učenje od vrtca do srednje šole (American Psychological Association, 2015). To načelo se opira na teoretske izpeljave Carol Dweck o pomenu tovrstnega razmišljanja ne le na področju izobraževanja otrok in mladih, temveč tudi na drugih področjih in tudi za odrasle (Dweck, 2007). 
Izhodišče pričujočega članka je, da ljudje različne psihološke lastnosti, na primer inteligentnost, lahko razumejo kot (bolj) nespremenljive, fiksne oziroma toge ali, na drugi strani, kot (bolj) spremenljive oziroma prožne (npr. Dweck in Yeager, 2019). Pola teh miselnosti imenujemo fiksna in razvojna miselnost. Obstajajo številne raziskave o teh miselnostih (npr. DeLuca, Coombs in LaPointe-McEwan, 2019; Dweck, 2012, Hwang, Reyes in Eccles, 2019; Lee in Seo, 2019, Macnamara in Rupani, 2017; Ng, 2018; Yan, Thai in Bjork, 2014), pozitivnih posledicah razvojne miselnosti za t. i. kognitivno blagostanje, na primer učno uspešnost, ter druge dimenzije blagostanja, kot so socialno, psihološko in fizično blagostanje (van Aalderen-Smeets in Walma van der Molen, 20r8; Bejjani, DePasque in Tricomi, 2019; Bostwick et al., 2019; Burnette et al., 2020; Costa in Faria, 2018; Leroy et al., 2007; Martin, 2015; Rattan, Good in Dweck, 2012; Sheldrake, 2016) ter tudi, ali glede privzemanja določene miselnosti obstaja razlika med spoloma (Dweck, 1986; Macnamara in Rupani, 2017; Hwang, Reyes in Eccles, 2019). V članku se naslanjamo na dihotomno razumevanje miselnosti, se pa raziskave ukvarjajo tudi z zveznim konstruktom (glej npr. Yeager in Dweck, 2019). Zaradi koristi, ki jih prinaša razvojna miselnost, veliko raziskav naslavlja spreminjanje fiksne miselnosti v razvojno (Bettinger et al., 2018; Good, Aronson in Inzlicht, 2003; Haimovitz in Dweck, 2016; Mrazek et al., 2018; Sisk et al., 2018). Lahko se zdi naravno, da bodo otroci staršev z razvojno miselnostjo tudi sami sprejemali razvojno miselnost. Vendar raziskave glede tega niso enoznačne (Gunderson et al., 2013; Park et al., 2016). Nekatere raziskave so opozorile na povezavo z načinom hvaljenja otrok (Gunderson et al., 20I3). Haimowitz in Dweck (2016) sta ugotovili, da je pri spodbujanju otrok k sprejemanju razvojne miselnosti pomembno, kako se odrasli odzivamo ob neuspehu: ali ga razumemo kot nekaj uničujočega ali kot izziv. Povezava s fiksno miselnostjo otrok se zdi smiselna, saj je pričakovati, da se otroci negativnemu odzivu odraslih na napako lahko prilagajajo tako, da se izogibajo situacijam, kjer bi napako lahko storili. To pa pomeni, da se izogibajo tudi situacijam, iz katerih bi se lahko nekaj naučili, kar privede do tega, da $v$ učenju zaostajajo za učenci, ki neuspeh sprejemajo kot pot do uspeha.

$\mathrm{V}$ članku najprej obravnavamo pojavnost fiksne miselnosti med slovenskimi is-letniki, osrednja tema pa je raziskovanje konteksta, ki ga za odnos med dejansko zmožnostjo in samopodobo učencev, ki sicer ni enoznačen (Marsh in Craven, 2006), ti miselnosti oblikujeta. Dunning (2005) in Ehrlinger et al. (2008) opisujejo, da ljudje težko natančno presodimo svoje dejanske zmožnosti. Praviloma naj bi bili preveč samozavestni, kar so poimenovali Dunning-Krugerjev učinek (Kruger in Dunning, 1999). Vendar so nadaljnje raziskave tem trditvam nasprotovale (Nuhfer 
et al., 2016; Nuhfer et al., 2017) in pokazale, da obstaja »dobra« povezava med dejansko zmožnostjo in samooceno ter da so v povprečju v samooceni bolj natančne ženske, medtem ko so moški nekoliko preveč samozavestni (Watson et al., 2019). Ehrlinger in Dweck (2016) sta si zastavili vprašanje o natančnosti samoocene študentov v normativni primerjavi z drugimi glede na miselnost, ki jo sprejemajo. Pokazali sta, da so v skupini študentov s preveliko samozavestjo študenti s fiksno miselnostjo še bolj samozavestni kot ostali.

$\mathrm{V}$ članku raziskujemo branje slovenskih I5-letnikov z uporabo podatkov PISA 2018 glede vprašanja, ali se sprejemanje fiksne miselnosti odraža v samopodobi, ki se ne ujema z dejanskimi zmožnostmi branja. Raziskave so pokazale, da se (bralna) samopodoba povezuje z (bralno) zmožnostjo v obe smeri, obe sta vzrok in posledica druga druge (Marsh in Craven, 2006). V članku analiziramo učinek dejanske zmožnosti branja na samopodobo učencev, in sicer primerjalno med učenci s fiksno miselnostjo in učenci z razvojno miselnostjo. Pri tem izhajamo iz tega, da če je, na primer, za učence s fiksno miselnostjo ob sicer enakem bralnem dosežku samopodoba višja od samopodobe učencev z razvojno miselnostjo, je smiselno vprašanje, ali gre za previsoko samopodobo učencev s fiksno miselnostjo ali prenizko samopodobo učencev z razvojno miselnostjo.

\section{Raziskovalna vprašanja}

Glede na zgoraj navedene raziskave o povezanosti med miselnostjo, dejanskimi zmožnostmi in samopodobo si zastavljamo naslednja raziskovalna vprašanja:

I) Ali je fiksna miselnost pogostejša med fanti kot dekleti?

Postavljamo domnevo, da se pogostost fiksne miselnosti med fanti in dekleti ne razlikuje, kar bi se skladalo z ugotovitvami Hwang, Reyes in Eccles (2019) ter Macnamara in Rupani (2017).

2) Ali je fiksna miselnost pogostejša med šibkejšimi kot med dobrimi bralci in bralkami?

Postavljamo domnevo, da je fiksna miselnost pogostejša pri učencih z nižjimi dosežki. To bi se skladalo z ugotovitvami Marsh et al. (2016) in Dweck (2008), vendar pa Hwang, Reyes in Eccles (2019) povezanosti z dosežki niso zaznali.

3) Ali se bralna samopodoba fantov in deklet s fiksno miselnostjo razlikuje od bralne samopodobe sovrstnikov z razvojno miselnostjo? 
Tudi tu postavljamo domnevo o negativni povezanosti fiksne miselnosti tako z dosežki kot s samopodobo. Predvidevamo, da so bralni dosež$\mathrm{ki}$ in bralna samopodoba fantov in deklet $s$ fiksno miselnostjo v povprečju nižji od dosežkov in samopodobe fantov in deklet z razvojno miselnostjo. To bi se skladalo z ugotovitvami Good, Rattan in Dweck (2012), Marsh et al. (2016) in Yeager et al. (2018).

4) Ali se pri šibkejših bralcih in bralkah učinek ${ }^{1}$ (povezanost) dejanske bralne pismenosti na bralno samopodobo ob fiksni miselnosti razlikuje od učinka ob razvojni miselnosti?

Naj pojasnimo, zakaj se omejujemo na šibkejše bralce in bralke. ${ }^{2}$ Marsh et al. (2016) so pokazali, da razvoj medsebojno vzročnega odnosa med dosežki in samopodobo ni preprost in da je vlaganje truda $v$ učenje (še posebno) za tiste z nižjo samopodobo »dvorezen meč«, saj je lahko njihova samopodoba še bolj poškodovana. $V$ članku se omejujemo na šibkejše bralce in bralke z namenom dobiti bolj jasno sliko konteksta fiksne miselnosti, za katero že ob tretjem raziskovalnem vprašanju domnevamo, da je med šibkejšimi bralci in bralkami pogostejša. Četrto raziskovalno vprašanje lahko razdelimo na dve podvprašanji:

4a) Ali se ob enaki bralni pismenosti bralna samopodoba učencev z razvojno in učencev s fiksno miselnostjo razlikuje?

4b) Ali se ob spremembi bralne pismenosti velikost spremembe bralne samopodobe učencev $\mathrm{z}$ razvojno in učencev $s$ fiksno miselnostjo razlikuje?

Ob manku raziskav in mešanih rezultatih nekaterih delno relevantnih predhodnih raziskav (Ehrlinger in Dweck, 2016; Watson et al., 2019; Sheldrake, 2016) tu postavljanje domnev ni neposredno. Glede na negativno povezanost fiksne miselnosti z dosežki, ki so jo ugotovile prej omenjene raziskave, postavljamo domnevo, da se bo samopodoba učencev $s$ fiksno miselnostjo od samopodobe tistih $\mathrm{z}$ razvojno miselnostjo razlikovala nasploh, kar naslavljamo $\mathrm{v}$ tretjem raziskovalnem vprašanju, in tudi v primerjavah skupin z enakimi bralnimi dosežki. Nadalje domnevamo, da se bo med skupinama razlikovala velikost spremembe $\mathrm{v}$ samopodobi, ki jo predstavlja enako višja bralna pismenost. ${ }^{3}$ Pri tem predvidevamo, da bodo ob enako višjih dosežkih učenci s fiksno miselnostjo izražali višjo

I Izraz »učinek « v članku uporabljamo v smislu standarda poročanja rezultatov regresijskih analiz (kar bomo uporabili kot analitični postopek za to raziskovalno vprašanje) in torej ne v smislu morebitnega vzročnega vpliva.

2 Natančna opredelitev je navedena v metodah.

3 Kar imenujemo naklon učinka višje pismenosti. 
samopodobo, kot bi jo pričakovali glede na njihove dosežke. To bi se skladalo z Ehrlinger in Dweck (2016).

\section{Metode}

$\mathrm{V}$ analizi bomo uporabili podatke iz raziskave PISA 20ı8, v kateri je bilo glavno področje preverjanja branje. Za vsebinski opis spektra zmožnosti branja, ki jih mladi izkažejo na preizkusu PISA, je mednarodna lestvica dosežkov razdeljena $\mathrm{v}$ hierarhično organizirane ravni bralne pismenosti oziroma ravni bralnih dosežkov (OECD, 20ı9a).

\section{Vzorec}

Vzorec slovenskih I5-letnikov, ki ga bomo uporabili za našo analizo, vključuje 640I učenca, od tega 2993 deklet in 3408 fantov, ki skupaj reprezentativno predstavljajo 17.138 učencev, od tega 49 odstotkov deklet in $5 \mathrm{I}$ odstotkov fantov. V analizah za prva tri raziskovalna vprašanja bomo uporabili podatke celotnega vzorca PISA 20 I8 za Slovenijo. Za zadnje raziskovalno vprašanje o učinku fiksne miselnosti na odnos med dosežki in samopodobo pa bomo uporabili vzorec t. i. šibkejših bralcev in bralk. S tem izrazom v članku opredeljujemo učence, ki so na mednarodni lestvici bralne pismenosti PISA dosegli rezultate na 3. ravni ali nižje. V vzorcu šibkejših bralcev in bralk je 4912 učencev, od tega 2091 deklet in 282 I fantov, ki skupaj reprezentativno predstavljajo I2.294 učencev, od tega 44 odstotkov deklet in 56 odstotkov fantov. Večji delež fantov med šibkejšimi bralci in bralkami je posledica v splošnem nižjih bralnih dosežkov fantov, kar je znano že iz drugih rezultatov (OECD, 2019a; Mullis et al., 2017).

\section{Mere}

Bralni dosežek: Bralni dosežki v raziskavi PISA so mednarodno primerljive mere zmožnosti branja (za več glej npr. OECD, 2019c). Bralni dosežek slovenskih is-letnikov je bil leta 2018 nad povprečjem OECD (495 točk na mednarodni lestvici v primerjavi s povprečjem OECD 487 točk (OECD, 2019a; Šterman Ivančič, 2019). Povprečni dosežek šibkejših bralcev in bralk, za katere bomo analize opravili posebej, pa je 455 točk.

Miselnost o (ne)spremenljivosti inteligence: Podatek o fiksni oziroma razvojni miselnosti izhaja iz vprašanja v vprašalniku PISA 2018 za učence o strinjanju s trditvijo »Tvoja inteligenca je nekaj, česar ne moreš bistveno spremeniti«, pri čemer so učenci izbirali med odgovori »Sploh se ne strinjam $\ll$, $\gg$ Ne strinjam se $\ll, ~ \gg$ Strinjam se $\ll$ in $\gg$ Popolnoma se strinjam $\ll$. Te odgovore smo dihotomizirali v strinjanje oziroma nestrinjanje. Za učence, ki so se strinjali s trditvijo, opredelimo, da sprejemajo fiksno miselnost, in za učence, ki se s trditvijo niso strinjali, da sprejemajo razvojno miselnost. 
Osnovna analiza teh podatkov, ki je na voljo v mednarodnem in nacionalnem poročilu o raziskavi (OECD, 2019a; Šterman Ivančič, 2019), pokaže, da se v Sloveniji sı odstotkov is-letnikov ne strinja s to trditvijo. Torej po naši opredelitvi 5 I odstotkov slovenskih Is-letnikov sprejema razvojno in 49 odstotkov fiksno miselnost.

Mere bralne samopodobe: V bazi PISA 2018 je na voljo več mer bralne samopodobe, ki jih podrobneje navajamo $\mathrm{v}$ nadaljevanju. $\mathrm{Za}$ vse mere velja, da so bili na podlagi odgovorov učencev na posamezne postavke $v$ sklopu vprašanj za določeno mero na mednarodni ravni izpeljani indeksi na intervalnih lestvicah tako, da je povprečje OECD enako o in standardni odklon I (v standardizaciji je vsem državam dodeljena enaka utež) (OECD, 2019c). Negativna vrednost indeksa v mednarodni bazi torej ne nakazuje negativnega odgovora na postavke, iz katerih je indeks izpeljan, ampak odgovore, ki so manj pozitivni (ali bolj negativni) od povprečnega odgovora v državah OECD. Podobno pozitivna vrednost nakazuje bolj pozitivne (ali manj negativne) odgovore od povprečnega odgovora $\mathrm{v} d \mathrm{~d}$ žavah OECD. Pri vseh merah bralne samopodobe so učenci za izkaz svojega (ne)strinjanja lahko izbirali med odgovori »Sploh se ne strinjam «, $\gg$ Ne strinjam se «, »Strinjam se « in »Popolnoma se strinjam «. Postavke $\mathrm{v}$ sklopih vprašanj za določeno mero zaradi berljivosti navajamo le v moški obliki.

Samopodoba o bralni kompetentnosti: Podatek je pridobljen na podlagi stopnje (ne)strinjanja z naslednjimi postavkami: »Sem dober bralec«, »Sposoben sem razumeti težka besedila« in »Tekoče berem «. Za učence $\mathrm{z}$ višjimi vrednostmi indeksa $\mathrm{v}$ naših interpretacijah navajamo, da izražajo višjo samopodobo ali da imajo višjo samopodobo, in za učence z nižjimi vrednostmi indeksa, da izražajo ali imajo nižjo samopodobo.

Zaznava težav pri branju nasploh: Podatek je pridobljen na podlagi stopnje (ne)strinjanja z naslednjimi postavkami: »Vedno sem imel težave z branjem «, »Besedilo moram večkrat prebrati, da bi ga popolnoma razumel « in »Težko mi je odgovoriti na vprašanja o besedilu«. Za učence $\mathrm{z}$ višjimi vrednostmi indeksa $\mathrm{v}$ naših interpretacijah navajamo, da zaznavajo več, višjo raven ali večji obseg težav oziroma več ali bolj zaznavajo težave pri svojem branju nasploh. Za učence z nižjimi vrednostmi indeksa navajamo, da tega zaznavajo manj.

Zaznava težav na preizkusu branja PISA: Vprašalnik za učence $\mathrm{v}$ raziskavi PISA 2018 je vključeval tudi vprašanje, kaj mislijo o bralnih nalogah v preizkusu PISA, ki so ga pravkar zaključili. Podatek o zaznavi težav na tem preizkusu je pridobljen na podlagi stopnje (ne)strinjanja z naslednjimi postavkami: »Veliko besed nisem razumel «, »Veliko besedil je bilo pretežkih zame« in »Izgubil sem se, ko sem moral krmariti med 
različnimi stranmi «. Za učence $\mathrm{z}$ višjimi vrednostmi indeksa v naših interpretacijah navajamo, da so na preizkusu zaznali več, višjo raven ali večji obseg težav oziroma več ali bolj zaznali težave. Za učence z nižjimi vrednostmi indeksa navajamo, da tako zaznavajo manj.

Za prvi oris teh mer so v Tabeli i njihove medsebojne korelacije.

Tabela I: Korelacije med merami bralne samopodobe in dosežki iz raziskave PISA 2018 za slovenske Is-letnike.

\begin{tabular}{lccc}
\multicolumn{1}{c}{$\begin{array}{c}\text { Mere bralne samopodobe in } \\
\text { dosežki }\end{array}$} & $\begin{array}{c}\text { Zaznava težav } \\
\text { pri branju } \\
\text { nasploh }\end{array}$ & $\begin{array}{c}\text { Zaznava težav } \\
\text { na preizkusu } \\
\text { branja PISA }\end{array}$ & Bralni dosežek \\
samopodoba o bralni kompetentnosti & $-0,40(0,02)$ & $-0,34(0,02)$ & $0,34(0,02)$ \\
\hline zaznava težav pri branju nasploh & $0,47(0,02)$ & $-0,24(0,01)$ \\
\hline zaznava težav na preizkusu branja PISA & & & $-0,34(0,02)$ \\
\hline
\end{tabular}

Opomba: Standardne napake so navedene v oklepajih.

Vir: Baza podatkov PISA 20I8, lastni izračuni.

Razvidno je, da vse mere bralne samopodobe in dosežki medsebojno korelirajo, kar govori v prid temu, da jih razumemo za kazalnike odnosa do lastnega branja. Največja korelacija je med zaznavo težav pri branju nasploh in zaznavo težav na preizkusu branja PISA, ki je o,47, kar je tudi po absolutni vrednosti največja korelacija.

\section{Analize}

Za prva tri raziskovalna vprašanja smo uporabili izračun povprečja mer, torej bralnega dosežka in zgoraj opisanih mer samopodobe, za relevantne skupine učencev glede na spol in glede na sprejemanje razvojne oziroma fiksne miselnosti. Razliko v povprečjih med relevantnimi skupinami ugotavljamo s t-testom. Te analize smo izvedli na celotnem vzorcu is-letnikov, ki so sodelovali v raziskavi PISA 20I8, za tretje raziskovalno vprašanje pa smo jih izvedli tudi za podskupino šibkejših bralcev in bralk.

$\mathrm{Za}$ četrto raziskovalno vprašanje smo uporabili linearno regresijsko analizo, ki smo jo izvedli le na podskupini šibkejših bralcev in bralk. S preliminarnimi analizami (na voljo pri soavtorici) smo preverili, ali je povezanost med bralnim dosežkom in merami samopodobe vsaj v grobem linearna.

Kriterijske spremenljivke v naših modelih linearne regresije so torej tri mere bralne samopodobe, napovednika pa sta bralni dosežek na preizkusu branja PISA 2or8, ki je zvezna spremenljivka, in dihotomizirani odgovor o sprejemanju razvojne oziroma fiksne miselnosti o inteligenci. V modele je vključen tudi križni učinek obeh napovednikov. Pri tem smo 
za boljšo predstavljivost rezultatov regresijske analize mere dosežkov in mere samopodobe standardizirali na skupino šibkejših bralcev in bralk. Ko v interpretacijah rezultatov regresijskih analiz govorimo o povprečjih in standardnih odklonih dosežkov in mer samopodobe, torej govorimo o povprečjih in razpršenosti teh mer znotraj skupine šibkejših bralcev in bralk.

Za analize smo uporabili statistični paket SPSS 24.0 in aplikacijo IDB Analyzer (IEA, brez datuma), kar je omogočalo izračun statističnih parametrov in njihovih populacijskih ocen ter standardnih napak $z$ uporabo ustreznih vzorčnih uteži in vseh deset ocen bralnega dosežka v bazi PISA 20I8. Z uporabo standardnih napak ocen je mogoče pri izbrani stopnji tveganja ugotavljati statistično pomembnost vzorčnih razlik. V članku statistično pomembnost ugotavljamo pri stopnji tveganja 5 odstotkov.

\section{Rezultati}

\section{Ali je fiksna miselnost pogostejša med fanti kot dekleti?}

Postavili smo domnevo, da razlik med spoloma v Sloveniji ni, kar bi se skladalo z rezultati Hwang, Reyes in Eccles (2019). Analiza je pokazala, da se je med slovenskimi I5-letniki, ki so leta 2018 sodelovali v raziskavi PISA, 48 odstotkov deklet in 49 odstotkov fantov strinjalo s trditvijo »Tvoja inteligenca je nekaj, česar ne moreš bistveno spremeniti«. Pri obeh spolih torej skoraj polovica sprejema fiksno miselnost. Razlika med spoloma ni statistično pomembna. Odgovor na prvo raziskovalno vprašanje je torej, da je sprejemanje fiksne miselnosti v Sloveniji enako (pre)pogosto med fanti in dekleti.

\section{Ali je fiksna miselnost pogostejša med šibkejšimi kot med dobrimi bralci in bralkami?}

Bralni dosežki so na mednarodni lestvici PISA opredeljeni po ravneh, od dosežkov pod I. ravnjo do dosežkov na najvišji, 6. ravni pismenosti. Ker imajo le majhni deleži učencev dosežke na najnižji oziroma najvišji ravni, smo za večjo preglednost in stabilnost rezultatov ravni dosežkov združili tako, da obravnavamo približno po tretjino učencev v skupinah z I) dosežki na 2. ravni ali nižje, kjer so bralni dosežki 33 odstotkov deklet in 52 odstotkov fantov, 2) dosežki na 3. ravni, kjer so bralni dosežki 33 odstotkov deklet in 26 odstotkov fantov, in 3) dosežki na 4. ravni ali višje, kjer so bralni dosežki 34 odstotkov deklet in 22 odstotkov fantov. Odstotki sprejemanja fiksne miselnosti po teh ravneh po spolu so predstavljeni v Tabeli 2. 
Tabela 2: Odstotki sprejemanja fiksne miselnosti po ravneh bralne pismenosti PISA po spolu.

\begin{tabular}{lcccc}
$\begin{array}{c}\text { Ravni bralne pismenosti } \\
\text { PISA }\end{array}$ & Vsi & $\begin{array}{c}\text { Dekleta } \\
(\mathrm{D})\end{array}$ & $\begin{array}{c}\text { Fantje } \\
(\mathrm{F})\end{array}$ & $\begin{array}{c}\text { Razlika } \\
(\mathrm{D}-\mathrm{F})\end{array}$ \\
$\begin{array}{l}\text { 2. raven ali nižje } \\
\text { 3. raven }\end{array}$ & $59(\mathrm{I}, 2)$ & $62(\mathrm{I}, 8)$ & $57(\mathrm{I}, 6)$ & $5(2,4)$ \\
\hline 4. raven ali višje & $44(\mathrm{I}, 5)$ & $47(2, \mathrm{I})$ & $42(2,0)$ & $4(2,9)$ \\
\hline skupaj & $38(\mathrm{I}, 5)$ & $36(\mathrm{I}, 9)$ & $4 \mathrm{I}(2,5)$ & $-5(3, \mathrm{I})$ \\
\hline
\end{tabular}

Opomba: Standardne napake so navedene v oklepajih.

Vir: Baza podatkov PISA 2018 , lastni izračuni.

Analiza pokaže, da z višjo bralno pismenostjo sprejemanje fiksne miselnosti upada. To velja tako za vse učence skupaj kot ločeno za dekleta in fante. Sklepamo lahko torej, da je pri šibkejših bralcih in bralkah sprejemanje fiksne miselnosti pogostejše. Pri tem nekoliko odstopajo fantje z višjimi dosežki, ki v podobnem deležu kot fantje s srednjimi dosežki sprejemajo fiksno miselnost (4I oziroma 42 odstotkov). Ta rezultat je še eden od pokazateljev razlik med spoloma glede branja in odnosa do njega.

\section{Ali se bralna samopodoba deklet in fantov s fiksno miselnostjo razlikuje od bralne samopodobe sovrstnikov $\mathrm{z}$ razvojno miselnostjo?}

Bralno samopodobo smo opredelili s tremi merami. To so: samopodoba o bralni kompetentnosti, zaznava težav pri branju nasploh in zaznava težav na preizkusu branja PISA. Na podlagi predhodnih raziskav smo domnevali, da se bodo razlike v bralnih dosežkih in bralni samopodobi med tistimi z razvojno in tistimi s fiksno miselnostjo pokazale tudi v naši analizi.

Analizo za to raziskovalno vprašanje smo izvedli dvakrat, prvič na celotni populaciji slovenskih I5-letnikov in drugič na izbrani podskupini šibkejših bralcev in bralk. V Tabeli 3 so predstavljeni rezultati analize za celotno populacijo slovenskih I5-letnikov in v Tabeli 4 za skupino šibkejših bralcev in bralk.

Rezultati analize kažejo jasne razlike v bralni samopodobi med tistimi z razvojno in tistimi s fiksno miselnostjo. Najprej, tako dekleta kot fantje $z$ razvojno miselnostjo imajo povprečno višje dosežke od deklet oziroma fantov s fiksno miselnostjo. Razlika pri dekletih je 36 točk in pri fantih 28 točk na mednarodni lestvici bralne pismenosti PISA. Kontekstualni pomen teh vrednosti lahko pridobimo iz podatka, da je razpon ene ravni bralne pismenosti na lestvici PISA opredeljen z 73 točkami (OECD, 20I9a); razlika v povprečnih dosežkih med dekleti z razvojno 
in dekleti s fiksno miselnostjo je torej polovica ene ravni dosežkov na mednarodni lestvici PISA. Pri fantih je ta razlika nekoliko manjša.

Tabela 3: Bralni dosežki in bralna samopodoba slovenskih I5-letnikov glede na sprejemanje fiksne oziroma razvojne miselnosti, po spolu.

\begin{tabular}{|c|c|c|c|c|}
\hline Dekleta & $\begin{array}{c}\text { Vsa } \\
\text { dekleta }\end{array}$ & $\begin{array}{c}\text { Razvojna } \\
\text { miselnost } \\
\text { ( } 52 \text { odstotkov) }\end{array}$ & $\begin{array}{c}\text { Fiksna } \\
\text { miselnost } \\
(48 \text { odstotkov })\end{array}$ & $\begin{array}{l}\text { Razlika } \\
\text { (razvojna } \\
\text { - fiksna) }\end{array}$ \\
\hline bralni dosežek & $517(1,9)$ & $536(2,6)$ & $500(3,1)$ & $36(3, \mathrm{I})$ \\
\hline $\begin{array}{l}\text { samopodoba o bralni } \\
\text { kompetentnosti }\end{array}$ & $0,17(0,02)$ & $0,25(0,03)$ & $0,09(0,03)$ & $0,16(0,04)$ \\
\hline $\begin{array}{l}\text { zaznava težav pri branju } \\
\text { nasploh }\end{array}$ & $-0,0 \mathrm{I}(0,02)$ & $-0,10(0,02)$ & $0,08(0,03)$ & $-0,18(0,04)$ \\
\hline $\begin{array}{l}\text { zaznava težav na preizku- } \\
\text { su branja PISA }\end{array}$ & $0,0 \circ(0,02)$ & $-0,14(0,03)$ & $0,14(0,03)$ & $-0,27(0,04)$ \\
\hline Fantje & Vsi fantje & $\begin{array}{c}\text { Razvojna } \\
\text { miselnost } \\
\text { ( } \text { I odstotkov) }\end{array}$ & $\begin{array}{c}\text { Fiksna } \\
\text { miselnost } \\
(49 \text { odstotkov) }\end{array}$ & $\begin{array}{l}\text { Razlika } \\
\text { (razvojna } \\
\text { - fiksna) }\end{array}$ \\
\hline bralni dosežek & $475(1,7)$ & $493(2,6)$ & $465(3,0)$ & $28(3,0)$ \\
\hline $\begin{array}{l}\text { samopodoba o bralni } \\
\text { kompetentnosti }\end{array}$ & $0,02(0,02)$ & $0,09(0,03)$ & $-0,05(0,03)$ & $0,14(0,04)$ \\
\hline $\begin{array}{l}\text { zaznava težav pri branju } \\
\text { nasploh }\end{array}$ & $-0,05(0,02)$ & $-0,11(0,03)$ & $0,01(0,03)$ & $-0,12(0,04)$ \\
\hline $\begin{array}{l}\text { zaznava težav na preizku- } \\
\text { su branja PISA }\end{array}$ & $-0,04(0,02)$ & $-0,17(0,03)$ & $\mathrm{O}, \mathrm{IO}(0,04)$ & $-0,27(0,05)$ \\
\hline
\end{tabular}

Opomba: Standardne napake so navedene v oklepajih.

Vir: Baza podatkov PISA 2or8, lastni izračuni.

Po drugi strani lahko razlike vrednotimo v standardiziranih vrednostih, izpeljanih za celotno populacijo slovenskih is-letnikov. ${ }^{4}$ Razlika v standardiziranih vrednostih bralnih dosežkov pri dekletih predstavlja 38 odstotkov standardnega odklona bralnih dosežkov v celotni populaciji, pri fantih pa 30 odstotkov.

Prav tako vse tri mere kažejo (povprečno) ugodnejšo bralno samopodobo za fante in dekleta $\mathrm{z}$ razvojno miselnostjo v primerjavi s sovrstniki s fiksno miselnostjo. Dekleta in fantje z razvojno miselnostjo imajo v povprečju višjo samopodobo o bralni kompetentnosti in zaznavajo manj težav pri branju v splošnem in na samem preizkusu branja PISA. Poglejmo te primerjave še v specifični skupini šibkejših bralcev in bralk, kar predstavljamo v Tabeli 4.

4 Tabelarični podatki so na voljo pri soavtorici. 
Tabela 4: Bralni dosežki in bralna samopodoba šibkejših bralcev in bralk glede na sprejemanje fiksne oziroma razvojne miselnosti, po spolu.

\begin{tabular}{|c|c|c|c|c|}
\hline Dekleta & $\begin{array}{c}\text { Vsa } \\
\text { dekleta }\end{array}$ & $\begin{array}{c}\text { Razvojna } \\
\text { miselnost } \\
\text { (46 odstotkov) }\end{array}$ & $\begin{array}{c}\text { Fiksna } \\
\text { miselnost } \\
\text { (54 odstotkov) }\end{array}$ & $\begin{array}{c}\text { Razlika } \\
\text { (razvojna } \\
\text { - fiksna) }\end{array}$ \\
\hline bralni dosežek & $473(2,6)$ & $487(3,7)$ & $464(3,3)$ & $23(4,7)$ \\
\hline $\begin{array}{l}\text { samopodoba o bralni } \\
\text { kompetentnosti }\end{array}$ & $0,00(0,02)$ & $0,04(0,03)$ & $-0,04(0,03)$ & $0,09(0,04)$ \\
\hline $\begin{array}{l}\text { zaznava težav pri bra- } \\
\text { nju nasploh }\end{array}$ & $0,13(0,02)$ & $0,04(0,03)$ & $0,20(0,03)$ & $-0,16(0,04)$ \\
\hline $\begin{array}{l}\text { zaznava težav na pre- } \\
\text { izkusu branja PISA }\end{array}$ & $0,20(0,02)$ & $0,08(0,03)$ & $0,29(0,04)$ & $-0,2 \mathrm{I}(0,05)$ \\
\hline Fantje & Vsi fantje & $\begin{array}{c}\text { Razvojna } \\
\text { miselnost } \\
\text { (48 odstotkov) }\end{array}$ & $\begin{array}{c}\text { Fiksna } \\
\text { miselnost } \\
\text { (52 odstotkov) }\end{array}$ & $\begin{array}{c}\text { Razlika } \\
\text { (razvojna } \\
\text { - fiksna) }\end{array}$ \\
\hline bralni dosežek & $442(2, I)$ & $456(2,9)$ & $434(2,7)$ & $22(3,6)$ \\
\hline $\begin{array}{l}\text { samopodoba o bralni } \\
\text { kompetentnosti }\end{array}$ & $-0,12(0,02)$ & $-0,07(0,03)$ & $-0,17(0,03)$ & $0,10(0,04)$ \\
\hline $\begin{array}{l}\text { zaznava težav pri bra- } \\
\text { nju nasploh }\end{array}$ & $0,04(0,02)$ & $-0,02(0,04)$ & $0,10(0,03)$ & $-0,11(0,05)$ \\
\hline $\begin{array}{l}\text { zaznava težav na pre- } \\
\text { izkusu branja PISA }\end{array}$ & $\mathrm{O}, \mathrm{II}(0,03)$ & $-0,0 \mathrm{I}(0,04)$ & $0,22(0,04)$ & $-0,23(0,05)$ \\
\hline
\end{tabular}

Opomba: Standardne napake so navedene v oklepajih.

Vir: Baza podatkov PISA 2018 , lastni izračuni.

Tudi za šibkejše bralce in bralke se kaže pozitivna povezanost razvojne miselnosti z bralnimi dosežki in bralno samopodobo, kot smo jo ugotovili za celotno populacijo slovenskih Is-letnikov. Šibkejše bralke z razvojno miselnostjo imajo povprečno višje bralne dosežke, višjo samopodobo o svoji bralni kompetentnosti, manj težav zaznavajo pri branju nasploh in poročajo o manj težavah na preizkusu branja PISA kot sovrstnice s fiksno miselnostjo. Šibkejši bralci imajo na splošno nižje ravni bralne samopodobe od šibkejših bralk, vendar pa so tudi pri teh fantih prisotne pozitivne povezave $\mathrm{z}$ razvojno miselnostjo - tisti $\mathrm{z}$ razvojno miselnostjo izkazujejo ugodnejše kazalnike dosežkov in samopodobe od sovrstnikov $s$ fiksno miselnostjo.

Ali so te korelacijske povezave za šibkejše bralce in bralke drugačne od povezav za celotno populacijo? Gledano v vrednostih indeksov iz baze PISA 2018, so razlike med šibkejšimi bralci in bralkami z razvojno miselnostjo in tistimi s fiksno miselnostjo v primerjavi s celotno populacijo, razumljivo, manjše pri dosežkih (ker so razlike med dosežki manjše), pri 
merah samopodobe pa je več podobnosti. Zanimivo je, da je največja podobnost glede zaznave težav pri branju nasploh.

Za pripravo konteksta nadaljnjih analiz znotraj skupine šibkejših bralcev in bralk poglejmo rezultate še v standardiziranih vrednostih, izpeljanih za to skupino (tabelarični podatki so pri soavtorici). Tako za dekleta kot fante je razlika $v$ bralnih dosežkih med tistimi z razvojno in tistimi s fiksno miselnostjo tudi v tem primeru skoraj tretjina standardnega odklona, razlika v zaznavanju težav na preizkusu branja PISA pa je med petino in četrtino standardnega odklona - torej nekoliko manjša, kot je razlika v standardiziranih vrednostih v celotni populaciji. To bi utegnilo izhajati iz tega, da so procesi oblikovanja samopodobe učno šibkejših učencev drugačni od procesov za učno uspešnejše učence (Marsh idr., 20I6).

\section{Ali se za šibkejše bralce in bralke učinek dejanske bralne pismenosti na bralno samopodobo ob fiksni miselnosti razlikuje od učinka ob razvojni miselnosti?}

Omenili smo že, da ima to raziskovalno vprašanje dve podvprašanji:

4a) Ali se ob enaki bralni pismenosti ravni bralne samopodobe med tistimi z razvojno in tistimi s fiksno miselnostjo razlikujejo?

4b) Ali se ob spremembi bralne pismenosti naklon spremembe bralne samopodobe med tistimi $\mathrm{z}$ razvojno in tistimi s fiksno miselnostjo razlikuje?

Z do sedaj opravljenimi primerjavami bralne samopodobe med skupinami 15 -letnikov z razvojno in fiksno miselnostjo smo predstavili splošno sliko na ravni povprečij mer $v$ teh skupinah. Iz teh primerjav je videti, da šibkejši bralci in bralke s fiksno miselnostjo ne le nimajo višje bralne samopodobe od sovrstnikov z razvojno miselnostjo, ampak imajo to samopodobo nižjo. To bi nasprotovalo uvodoma povzetim ugotovitvam Ehrlinger in Dweck (2016) o previsoki samopodobi tistih s fiksno miselnostjo.

Vendar v dosedanjih analizah nismo upoštevali, da dejanska zmožnost branja, ki je tudi med šibkejšimi bralci in bralkami raznolika, igra vlogo v oblikovanju samopodobe. Naslavljanje domneve o preveliki samopodobi je zato treba zasnovati kot obravnavo razlik v samopodobi med tistimi z razvojno in tistimi s fiksno miselnostjo, ki imajo sicer podobne bralne dosežke. Podobno se lahko vprašamo, kakšen je učinek višjih dosežkov na višjo samopodobo za skupino z razvojno in za skupino s fiksno miselnostjo. Tovrstne učinke smo analizirali z regresijsko analizo posameznih mer samopodobe, pri čemer smo kot napovednik uporabili bralni 


\section{dosežek in obenem $v$ model vključili križni učinek fiksne miselnosti. Rezultati so predstavljeni v Tabeli 5 .}

Tabela s: Rezultati regresijske analize učinka bralne zmožnosti na štiri mere bralne samopodobe glede na fiksno oziroma razvojno miselnost za skupino šibkejših bralcev in bralk.

\begin{tabular}{lcc}
\multicolumn{1}{c}{ Samopodoba o bralni kompetentnosti } & Dekleta & Fantje \\
\hline delež pojasnjene variance $\left(\mathrm{R}_{2}\right)$ & $0,05(0,0 \mathrm{I})$ & $0,04(0,0 \mathrm{I})$ \\
\hline $\begin{array}{l}\text { raven samopodobe ob povprečnem dosežku in razvojni miselnosti } \\
\text { (konstanta) }\end{array}$ & $0,03(0,03)$ & $0,00(0,03)$ \\
\hline $\begin{array}{l}\text { sprememba ravni samopodobe ob povprečnem dosežku in fiksni } \\
\text { miselnosti }\end{array}$ & $-0,02(0,05)$ & $-0,06(0,05)$ \\
\hline naklon učinka bralne pismenosti ob razvojni miselnosti & $0,23(0,04)$ & $0,24(0,04)$ \\
\hline $\begin{array}{l}\text { sprememba v naklonu učinka bralne pismenosti ob fiksni miselnosti } \\
\text { (križni učinek) }\end{array}$ & $0,00(0,05)$ & $-0,07(0,06)$ \\
\hline
\end{tabular}

\section{Zaznava težav pri branju nasploh}

\begin{tabular}{lcc} 
delež pojasnjene variance $\left(\mathrm{R}_{2}\right)$ & $0,04(0,0 \mathrm{I})$ & $0,03(0,0 \mathrm{I})$ \\
\hline $\begin{array}{l}\text { raven zaznave ob povprečnem dosežku in razvojni miselnosti } \\
\text { (konstanta) }\end{array}$ & $0,05(0,03)$ & $-0, \mathrm{IO}(0,04)$ \\
\hline $\begin{array}{l}\text { sprememba ravni zaznave ob povprečnem dosežku in fiksni } \\
\text { miselnosti }\end{array}$ & $0, \mathbf{I 0}(0,04)$ & $0,05(0,05)$ \\
\hline naklon učinka bralne pismenosti ob razvojni miselnosti & $-0,22(0,04)$ & $-0, \mathrm{IO}(0,04)$ \\
\hline $\begin{array}{l}\text { sprememba v naklonu učinka bralne pismenosti ob fiksni miselnosti } \\
\text { križni učinek) }\end{array}$ & $0,04(0,06)$ & $-0, \mathbf{I} 4(0,07)$ \\
\hline
\end{tabular}

\section{Zaznava težav na preizkusu branja PISA}

\begin{tabular}{lcc} 
delež pojasnjene variance $\left(\mathrm{R}_{2}\right)$ & $0,06(0,01)$ & $0,06(0,02)$ \\
\hline $\begin{array}{l}\text { raven zaznave ob povprečnem dosežku in razvojni miselnosti } \\
\text { (konstanta) }\end{array}$ & $0,02(0,04)$ & $-0,16(0,04)$ \\
\hline $\begin{array}{l}\text { sprememba ravni zaznave ob povprečnem dosežku in fiksni } \\
\text { miselnosti }\end{array}$ & $0,15(0,05)$ & $0,16(0,05)$ \\
\hline naklon učinka bralne pismenosti ob razvojni miselnosti & $-0,22(0,04)$ & $-0,18(0,04)$ \\
\hline $\begin{array}{l}\text { sprememba v naklonu učinka bralne pismenosti ob fiksni miselnosti } \\
\text { križni učinek) }\end{array}$ & $-0,03(0,05)$ & $-0,07(0,07)$ \\
\hline
\end{tabular}

Opomba: Analize so opravljene na standardiziranih vrednostih vseh zveznih mer. Standardne napake so v oklepajih. Statistično pomembne vrednosti so v krepkem tisku.

Vir: Baza podatkov PISA 20ı8, lastni izračuni.

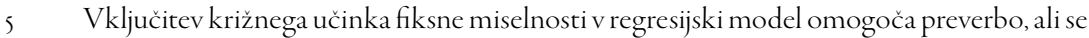
odnos med dosežki in samopodobo za tiste s fiksno miselnostjo razlikuje od tega odnosa za tiste z razvojno miselnostjo. 
Najprej povejmo, da z modeli učinkov bralnih dosežkov na mere bralne samopodobe $v$ naši analizi pojasnimo le manjše deleže variance $v$ bralnih samopodobah, največ do 6 odstotkov. To je pričakovano, saj so regresijski modeli zelo preprosti, na oblikovanje samopodobe pa znano deluje še vrsta drugih (prepoznanih in neprepoznanih) dejavnikov (Marsh in Craven, 2006). Vendar s preprostim regresijskim modelom poskušamo ohranjati jasnost interpretacij o povezanosti med bralno pismenostjo in bralno samopodobo ter kontekstom, ki ga pri tem določa miselnost o (ne)spremenljivosti inteligence.

Poglejmo podrobneje rezultate regresijskih analiz za posamezne mere bralne samopodobe. ${ }^{6}$

\section{Samopodoba o bralnikompetentnosti}

Za samopodobo o bralni kompetentnosti lahko iz rezultatov naše analize razberemo, da imajo dekleta s povprečnim dosežkom (med šibkejšimi bralci in bralkami - torej povprečno šibke bralke) približno povprečno (glede na šibkejše bralce in bralke) raven samopodobe o svoji bralni kompetentnosti (konstanta 0,03 ); to velja tako za tiste $\mathrm{z}$ razvojno kot za tiste $\mathrm{s}$ fiksno miselnostjo (koeficient spremembe v samopodobi ob fiksni miselnosti ni statistično pomemben). Naklon učinka bralne pismenosti na samopodobo ob razvojni miselnosti je 0,23, kar pomeni, da je med dvema skupinama šibkejših bralk z razvojno miselnostjo, ki se po bralnem dosežku razlikujeta za en standardni odklon (znotraj celotne skupine šibkejših bralcev in bralk), povprečna razlika v bralni samopodobi o,23 standardnega odklona te mere (zopet znotraj celotne skupine, ki jo analiziramo). Pri tem imajo višjo bralno samopodobo dekleta $z$ višjimi dosežki. Za šibkejše bralke z razvojno miselnostjo višji dosežek tako predstavlja za 23 odstotkov standardnega odklona višjo bralno samopodobo.

Križnega učinka fiksne miselnosti šibkejših bralk v tem odnosu nismo zaznali. To pomeni, da je naklon učinka za šibkejše bralke s fiksno miselnostjo podoben naklonu za tiste $\mathrm{z}$ razvojno miselnostjo. Ob enakih dosežkih imajo torej šibkejše bralke podobno samozavest glede svojega branja ne glede na to, ali sprejemajo fiksno ali razvojno miselnost, in za oboje višji dosežki predstavljajo tudi enako višjo samozavest. Razlika v nižji povprečni bralni samopodobi deklet $s$ fiksno miselnostjo od deklet $\mathrm{z}$ razvojno miselnostjo, ki smo jo zaznali $\mathrm{v}$ analizi za tretje raziskovalno vprašanje, tako verjetno izhaja iz tega, da imajo na splošno dekleta s fiksno miselnostjo tudi nekoliko nižje bralne dosežke (Tabela 3). Analiza za četrto raziskovalno vprašanje pa kaže, da je odnos med dosežki

6 V interpretacijah rezultatov v nadaljevanju za vsa povprečja in standardne odklone velja, da govorimo o skupini šibkejših bralcev in bralk. 
in samopodobo pri dekletih enak, ne glede na to, ali sprejemajo razvojno ali fiksno miselnost.

Za povprečno šibko bralno pismene fante $\mathrm{z}$ razvojno miselnostjo analiza kaže, da, tako kot dekleta, izražajo povprečno raven samopodobe o bralni kompetentnosti (konstanta ०,০০). Sprememba v samopodobi za fante s fiksno miselnostjo ni statistično pomembna (koeficient - $-0,06$ ), zato tudi fantje s fiksno miselnostjo in povprečnimi dosežki izražajo povprečno samopodobo. Sprememba v samopodobi ob višjih dosežkih je za fante $\mathrm{z}$ razvojno miselnostjo 0,24 ; učinek za en standardni odklon višjega dosežka je tako v 24 odstotkih višji bralni samopodobi teh fantov. Tudi pri fantih križnega učinka fiksne miselnosti nismo zaznali (koeficient $-0,07$ ni statistično pomemben).

Ugotavljamo, da je odnos med bralnimi dosežki in samopodobo o bralni kompetentnosti pri obeh spolih podoben ne glede na sprejemanje razvojne ali fiksne miselnosti: povprečno šibki bralci in bralke izražajo povprečno samozavest (znotraj obravnavane skupine šibkejših bralcev in bralk) in za vse višja bralna pismenost predstavlja približno enako višjo samozavest. Iz tega lahko za celotno skupino šibkejših bralk in bralcev sklepamo, da sprejemanje fiksne miselnosti ne spreminja odnosa med njihovima bralno pismenostjo in samopodobo o bralni kompetentnosti. Še več, samopodoba o bralni kompetentnosti je enaka za vse enako šibko bralno pismene. To predstavlja pomembno izhodišče za interpretacije rezultatov nadaljnjih analiz zaznavanja težav pri branju. Domnev o previsoki ali prenizki samozavesti tistih $s$ fiksno miselnostjo v primerjavi s tistimi z razvojno miselnostjo s to analizo torej nismo potrdili.

\section{Zaznava težav pri branju nasploh}

Povprečno šibke bralke z razvojno miselnostjo zaznavajo povprečno raven težav pri svojem branju nasploh (konstanta $0,05 \mathrm{ni}$ statistično pomembna). Enako pismene bralke $s$ fiksno miselnostjo zaznavajo več težav pri branju (koeficient spremembe je o,IO in je statistično pomemben; raven zaznavanja težav skupaj je o,0 $+0,10=0,15$, kar predstavlja Is odstotkov standardnega odklona nadpovprečno zaznavo težav). Rezultati torej kažejo, da fiksna miselnost pri teh dekletih, kljub enakim dosežkom, učinkuje $\mathrm{v}$ večji zaznavi bralnih težav. Zdi se torej, da so ta dekleta premalo samozavestna. ${ }^{7}$ Več bomo vedeli nekoliko kasneje, ko bomo obravnavali zaznavo težav na preizkusu branja PISA.

Za šibkejše bralke z razvojno miselnostjo se učinek bralne pismenosti na zaznavo težav kaže v za 22 odstotkov standardnega odklona manjši

7 Izraz $\gg$ samozavest $\ll$ v interpretacijah uporabljamo poenostavljeno kot sinonim za samopodobo. 
zaznavi teh težav. Višja bralna pismenost teh deklet v povprečju predstavlja za petino standardnega odklona manjšo zaznavo težav pri branju nasploh. Rezultat je pričakovan, saj je smiselno, da se višja bralna zmožnost odraža v manj težavah pri branju in so torej odgovori o zaznavi manj teh težav s tem usklajeni. Nadalje analiza pokaže, da fiksna miselnost deklet v tem odnosu nima križnega učinka. Tudi za šibkejše bralke s fiksno miselnostjo višja bralna pismenost predstavlja približno petino standardnega odklona manj zaznavanja težav pri branju nasploh.

Drugače je pri fantih. Povprečno šibki bralci z razvojno miselnostjo zaznavajo manj težav pri branju kot enako pismena in enako misleča dekleta (koeficient za fante -o,ı je statistično pomemben). To velja tudi za povprečno šibke bralce $s$ fiksno miselnostjo, saj dodatnega učinka fiksne miselnosti pri tem ni. Ne glede na miselnost povprečno šibki bralci torej zaznavajo za približno desetino standardnega odklona manj težav pri branju nasploh od enako pismenih deklet $\mathrm{z}$ razvojno miselnostjo (dekleta $s$ fiksno miselnostjo pa teh težav zaznavajo več).

Smiselno se je vprašati, čigava samopodoba je pri tem neustrezna. Odgovor je mogoče opreti na predhodne ugotovitve o enaki samopodobi bralne kompetentnosti enako šibko pismenih pri obeh spolih. Zaznavanje težav pri branju od te »povprečnosti« odstopa pri fantih, zato se zdi smiselno sklepati o neustreznosti njihove, torej prevelike, samozavesti. Več bomo vedeli ob obravnavi zaznavanja težav na preizkusu branja PISA.

Višji dosežki predstavljajo manj zaznavanja težav pri branju nasploh tudi pri razvojno mislečih šibkejših bralcih, vendar z manjšim naklonom kot pri dekletih. Za šibkejše bralce $z$ razvojno miselnostjo je učinek za en standardni odklon višjih bralnih dosežkov v približno za ıo odstotkov standardnega odklona manj zaznavanja težav. Dodatni učinek fiksne miselnosti pri fantih je -o, I 4, kar pove, da fantje s fiksno miselnostjo ob za en standardni odklon višji bralni pismenosti poročajo o za približno četrtino standardnega odklona manj zaznave splošnih bralnih težav $((-0,10)$ $\left.+\left(-0,1_{4}\right)=-0,24\right)$. Ta naklon je podoben kot pri dekletih.

So torej fantje $\mathrm{z}$ razvojno miselnostjo premalo samozavestni ali fantje s fiksno miselnostjo preveč? Tu je odgovor nekoliko bolj kompleksen. Najprej upoštevamo, da so povprečno šibki bralci (ne glede na miselnost) bolj samozavestni glede zaznavanja težav pri branju od enako bralno pismenih deklet. Zaradi položnejšega naklona se zdi, da se ob višjih dosežkih samozavest razvojno mislečih fantov uravnava s samozavestjo deklet, fantje s fiksno miselnostjo pa s strmejšim naklonom ohranjajo razliko s samozavestjo deklet tudi ob višjih, ne le povprečnih, dosežkih. Če za izhodišče vzamemo, da so ne glede na miselnost povprečno šibki bralci preveč samozavestni, fantje s fiksno miselnostjo to preveliko samozavest ohranjajo 
tudi ob višjih dosežkih, fantje z razvojno miselnostjo pa jo ob višjih dosežkih popravljajo.

\section{Zaznava težav na preizkusu branja PISA}

Ta mera je ključnega pomena za našo analizo. V raziskavi PISA 2018 sodelujoči učenci so bili v spremljajočem vprašalniku vprašani o zaznavi težav na pravkar zaključenem preizkusu branja. Ker so bralni dosežki, ki jih $\mathrm{v}$ naši analizi (in nasploh $\mathrm{v}$ raziskavi PISA) uporabljamo za kazalnik dejanske bralne pismenosti, izpeljani iz njihove uspešnosti na tem preizkusu, nam odgovori učencev o zaznavanju težav na tem preizkusu omogočajo dodaten vpogled $\mathrm{v}$ njihovo doživljanje lastnega branja. Za dva učenca $\mathrm{z}$ enakimi dosežki bi v idealni povezanosti dosežkov z zaznavanjem težav na preizkusu pričakovali, da bosta enako oziroma podobno odgovorila o teh težavah. Ob predstavitvi mer bralne samopodobe smo v Tabeli I navedli tudi medsebojne korelacije teh mer in dosežkov, ki kažejo, da je korelacija med bralnim dosežkom in zaznavo težav na preizkusu branja PISA »le« $-0,34$ (popolna korelacija bi bila -I). Četrto raziskovalno vprašanje izhaja iz zanimanja, ali na to korelacijo dodatno učinkuje tudi fiksna miselnost. Smiselno je pričakovati, da so zaznave težav pri branju nasploh podobne, seveda pa ne skladne, z zaznavami težav na preizkusu branja PISA. Korelacija med tema dvema merama, predstavljena v Tabeli I, je o,47 (popolna bi bila enaka I). Četrto raziskovalno vprašanje izhaja tudi iz zanimanja, ali sta povezanosti bralne pismenosti s tema merama zaznavanja težav medsebojno podobni in ali ima pri tem fiksna miselnost dodatni učinek.

Analiza kaže, da so povprečno šibke bralke $\mathrm{z}$ razvojno miselnostjo zaznale povprečen obseg težav na preizkusu branja PISA (konstanta o,O2), enako šibke bralke s fiksno miselnostjo pa poročajo o 17 odstotkov standardnega odklona nadpovprečnem obsegu teh težav (sprememba o,I5, oziroma skupen koeficient $0,02+0,15=0,17)$. Ob enakih dosežkih na istem, pravkar zaključenem preizkusu branja, na katerem so se oboja dekleta najverjetneje soočala s približno enakim obsegom težav, povprečno bralno šibko pismena dekleta s fiksno miselnostjo poročajo o več težavah kot enako bralno pismena dekleta z razvojno miselnostjo. Sklepamo lahko, da so šibkejše bralke s fiksno miselnostjo premalo samozavestne glede teh težav. To dodatno podkrepi razumevanje, da je tudi prej ugotovljeno večje zaznavanje težav pri branju nasploh pri teh dekletih izkaz prenizke samozavesti. Zanimivo je torej, da se fiksna miselnost deklet ne odraža $v$ samopodobi o bralni kompetentnosti, ampak v zaznavanju težav.

Naklon učinka višje bralne pismenosti na zmanjšanje zaznave teh težav je pri dekletih (ne glede na njihovo miselnost) približno petina do 
četrtina standardnega odklona. Rezultat je torej podoben rezultatom za splošno branje deklet.

Fantje se tudi pri tej meri bralne samopodobe razlikujejo od deklet. Podobno kot za težave pri branju nasploh povprečno šibki bralci z razvojno miselnostjo poročajo o manjšem obsegu težav na preizkusu branja PISA od enako pismenih deklet $s$ katerokoli miselnostjo (raven zaznave je -o,16). So ti fantje preveč samozavestni? Tudi ti fantje imajo povprečno šibke dosežke, kar pomeni, da so se verjetno soočali s približno enakim obsegom težav na preizkusu PISA kot dekleta z enakimi dosežki. Obenem imajo, enako kot dekleta, povprečno samopodobo o bralni kompetentnosti. Njihovo poročanje o manj težavah na preizkusu se zato ne zdi realno. To dodatno podkrepi razumevanje, da je tudi pri teh fantih prej ugotovljeno manjše zaznavanje težav pri branju nasploh izkaz previsoke samozavesti. Zanimivo pa je, da pri tem ne gre za šibkejše bralce s fiksno, ampak $z$ razvojno miselnostjo.

Kaj pa šibkejši bralci s fiksno miselnostjo? V nasprotju z njihovim zaznavanjem težav pri branju nasploh so povprečno šibko pismeni fantje s fiksno miselnostjo poročali o več težavah na preizkusu branja PISA od enako pismenih razvojno mislečih sovrstnikov (koeficient spremembe ob fiksni miselnosti je o,I6, kar pomeni, da je skupni koeficient ravni zaznave težav -0,16 + o,16 = 0,00). Ti fantje torej poročajo o povprečnem obsegu težav, kar je podobno poročanju povprečno šibkih razvojno mislečih bralk. To se zdi realen rezultat. Fiksna miselnost za te fante pri tem vprašanju ne kaže negativnih učinkov. Ostaja pa vtis o previsoki samozavesti iz odgovorov o težavah pri branju nasploh.

Naklon učinka višje bralne pismenosti na manj zaznavanja težav na preizkusu PISA je (ne glede na miselnost) za šibkejše bralce približno petina standardnega odklona. Rezultat je podoben rezultatom deklet. Dodatnega učinka fiksne miselnosti v tem odnosu bralne zmožnosti z zaznavo težav na preizkusu branja PISA nismo ugotovili ne pri dekletih ne pri fantih. Glede na stabilnost med spoloma in med učenci z različnimi miselnostmi ter podobnost $\mathrm{z}$ mero zaznavanja težav pri branju nasploh, nenazadnje pa tudi glede na to, da govorimo o zaznavanju težav na preizkusu, iz katerega so izpeljani dosežki, ki so za vse v primerjanih skupinah (približno) enaki, sklepamo, da je ta rezultat realen. Rezultati torej nakazujejo, da so težave na preizkusu PISA realno zaznavali šibkejše bralke z razvojno pismenostjo in šibkejši bralci s fiksno miselnostjo; šibkejše bralke $s$ fiksno miselnostjo pa so premalo, šibkejši bralci z razvojno miselnostjo preveč samozavestni. 


\section{Razprava}

Se fiksna miselnost odraža v neustrezni samopodobi? V nekaterih primerih se zdi, da se. Rezultati naših analiz kažejo, da razlik med spoloma v pogostosti sprejemanja fiksne miselnosti ni, tudi ko jih gledamo po ravneh bralne pismenosti, za katero je znano, da dekleta v povprečju dosegajo višje rezultate od fantov (prvo in drugo raziskovalno vprašanje). Znano je tudi, da je bralna samopodoba med dekleti in fanti na splošno različna (OECD, 2019a; Mullis et al., 2017), v naših analizah pa smo prepoznali tudi različnost znotraj spolov glede na miselnost, ki jo sprejemajo (tretje raziskovalno vprašanje). Rezultati jasno kažejo pozitivne (korelacijske) učinke razvojne miselnosti $v$ smislu boljših rezultatov v dosežkih in samopodobi za dekleta oziroma fante $\mathrm{z}$ razvojno miselnostjo $\mathrm{v}$ primerjavi $\mathrm{z}$ rezultati sovrstnikov istega spola s fiksno miselnostjo. Ti učinki se kažejo za vse tri mere samopodobe iz baze PISA 20ı8. Podobno smo pozitivne učinke razvojne miselnosti prepoznali v obravnavi le šibkejših bralcev in bralk (tudi tretje raziskovalno vprašanje). Ti rezultati se skladajo z uvodoma navedenimi raziskavami in našimi postavljenimi domnevami.

Potem smo vzorce odnosov med fiksno miselnostjo, bralnimi dosež$\mathrm{ki}$ in bralno samopodobo raziskovali ob uravnavi primerjav le med tistimi s podobnimi dosežki (četrto raziskovalno vprašanje). Prej nakazani pozitivni učinki razvojne miselnosti pri vseh treh merah samopodobe so se nekoliko spremenili. Rezultati najprej kažejo, da imajo povprečno šibki bralci in bralke vsi povprečno šibko samopodobo o bralni kompetentnosti (torej enako raven te samopodobe), nekaj višja pismenost pa pri vseh predstavlja približno enako višjo samopodobo. Glede na stabilnost teh rezultatov po vseh podskupinah po spolu in po miselnostih jih avtorja ocenjujeva za realne.

Zaznavanje težav pa pokaže povsem drugo dimenzijo v samopodobi. Povprečno šibke bralke z razvojno miselnostjo zaznavajo (za šibkejše bralce in bralke) povprečen obseg težav tako pri branju nasploh kot na preizkusu PISA. Višja pismenost pri teh dekletih predstavlja manj zaznavanja težav, kar je pričakovano. Enako šibke bralke s fiksno miselnostjo zaznavajo več težav, tako pri branju nasploh kot na preizkusu PISA. Ker imajo na preizkusu PISA enake dosežke kot sovrstnice z razvojno miselnostjo, lahko sklepamo, da se fiksna miselnost pri teh dekletih odraža v prenizki samozavesti. Ali pa so dekleta $\mathrm{z}$ razvojno miselnostjo samozavestna preveč? $\mathrm{Z}$ naslanjanjem na »povprečnost « samopodobe o bralni kompetentnosti za vse primerjane skupine avtorja meniva, da gre za prenizko samozavest deklet s fiksno miselnostjo. 
Fantje, ne glede na enake dosežke, o zaznavanju težav poročajo drugače. Povprečno šibki bralci obeh miselnosti zaznavajo podpovprečen obseg težav pri branju nasploh. $\mathrm{Z}$ izhodiščem »povprečnosti« pri bralni kompetentnosti iz tega sklepamo, da so šibki bralci glede svojih težav pri branju preveč samozavestni. Vendar glede teh težav nekoliko višja bralna pismenost šibkejših bralcev z razvojno miselnostjo predstavlja manj povečano samozavest, kot je ta naklon pri šibkejših bralkah. Zdi se, da se ob višjih dosežkih prevelika samozavest teh fantov nekoliko »popravlja«. Ne pa fantov s fiksno miselnostjo, za katere nekoliko višja pismenost predstavlja enak naklon višje samozavesti kot za dekleta. Zdi se, da fiksna miselnost fante dodatno ovira pri realnem prepoznavanju primanjkljajev $\mathrm{v}$ branju.

Vendar je zanimivo, da se ta negativni učinek fiksne miselnosti fantov ne pokaže pri zaznavanju težav na preizkusu branja PISA. Medtem ko povprečno šibki bralci z razvojno miselnostjo, podobno kot za branje nasploh, poročajo o podpovprečnem obsegu težav na preizkusu PISA, povprečno šibki bralci s fiksno miselnostjo poročajo o povprečnem obsegu teh težav, kar se, glede na ostala izhodišča, zdi realna samoocena.

Rezultate naših analiz za četrto raziskovalno vprašanje lahko delno primerjamo s predhodnimi raziskavami. Naši rezultati glede poročanja šibkejših bralcev o lastnih težavah pri branju se povezujejo z rezultati Ehrlinger in Dweck (2016), ki sta sicer preveliko samozavest tistih s fiksno miselnostjo ugotovili glede normativnih samoprimerjav posameznika $\mathrm{z}$ drugimi člani analizirane skupine. $\mathrm{O}$ razlikah med spoloma avtorici ne govorita, je pa zanimivo, da sta pokazali, da je posrednik med fiksno miselnostjo in preveliko samozavestjo izogibanje posvečanja pozornosti težavnejšim nalogam (ibid). To se zdi smiselno, če ob tem domnevamo, da se ob težavnejših nalogah tistim s fiksno miselnostjo vzbujajo strahovi, da bodo razkrinkani glede svoje nesposobnosti. Čeprav Watson et al. (2019) v svojih analizah prevelike samozavesti niso naslavljali primerjav med fiksno in razvojno miselnostjo, se naši rezultati za zaznavanje težav pri branju nasploh in delno za zaznavanje težav na preizkusu branja PISA skladajo z njihovimi ugotovitvami, da so ženske bolj realistične v samoocenah in moški nekoliko preveč samozavestni.

Naše rezultate lahko povežemo tudi z rezultati Marsh et al. ( 2016) $\mathrm{o} \gg$ dvoreznosti « vlaganja truda, $s$ katerimi lahko dodatno pojasnimo, zakaj smo pri samopodobi o bralni kompetentnosti zaznali »povprečnost «, pri zaznavanju težav pa ne. Zaznavanje težav lahko namreč predstavlja pritisk za vlaganje truda. Avtorji so v raziskavi pokazali, da je za učence $\mathrm{z}$ relativno nizko učno samopodobo na nekem področju (raziskava se je nanašala na matematiko), ki torej v učni situaciji verjetneje pričakujejo neuspeh, 
vlaganje truda v učenje lahko »dvorezen meč«. Če jim kljub dodatnemu trudu ne uspe, bo njihova samopodoba dodatno poškodovana, saj se bo tako potrdilo, da so neuspešni, pa če se še tako trudijo. Učencem, ki pričakujejo neuspeh, je zaradi ščitenja lastne samopodobe bolj smiselno, da truda ne vlagajo, saj jim tako ostane izgovor, da je neuspeh posledica netruda, ne pa neke njihove nespremenljive slabosti, na primer neinteligentnosti (ibid). Iz tega razberemo, da je lahko kljub temu, da je relativno nizka, samopodoba teh učencev še vedno previsoka glede na njihove zmožnosti. Pri tem avtorji o razlikah med spoloma ne govorijo in mogoče je, da so naši rezultati pokazali razlike med spoloma zaradi obravnave področja branja. Na mednarodni ravni so razlike med spoloma v dosežkih pri matematiki v primerjavi z branjem precej manjše in precej manj konsistentne med državami (npr. OECD 2019a; Mullis et al., 2016). Če v razmisleku upoštevamo še model razvoja samopodobe $s$ t. i. notranjimi in zunanjimi primerjavami (Marsh et al., 20I5), ki govori o medsebojnih (negativnih) interakcijah dosežkov in samopodob na različnih področjih, na primer med bralnimi dosežki in matematično samopodobo tako, da dobri bralni dosežki negativno učinkujejo na matematično samopodobo in dobri matematični dosežki negativno učinkujejo na bralno samopodobo, si ni težko predstavljati, kako se za šibkejše bralce nižja bralna samopodoba gradi postopno skozi leta, z njo pa lahko nastaja vrsta samooviralnih vedenj (Covington, 1992) z namenom ohranjanja (vsaj zasilno) pozitivne samopodobe.

Če pritegnemo uvodoma omenjene ugotovitve Haimowitz in Dweck (2016), lahko postavimo nadaljnje domneve o tem, da otroci razvijajo razvojno miselnost, če pri odraslih zaznavajo soočanje $s$ težavami in smiselno vlaganje truda namesto samooviralnih vedenj. Vendar Yaeger in Dweck (2019) svarita pred enačenjem spodbujanja razvojne miselnosti zgolj s spodbujanjem vlaganja truda, kar lahko privede do t. i. navidezne razvojne miselnosti ali pa razumevanja, da je za neuspeh pač kriv učenec (Levy et al., iz Yeager in Dweck 2019). Yeager (2018) pri tem opozarja na pomembno razliko med otroci in mladostniki: $v$ nasprotju $\mathrm{z}$ delom $\mathrm{z}$ otroki je pri delu z (včasih trdovratno uporniškimi) mladostniki treba upoštevati tudi njihovo intenzivirano potrebo po spoštovanju s strani odraslih in priznavanju statusa.

Kaj so prednosti in slabosti naše raziskave? Medsebojna interakcija med zmožnostjo in samopodobo je del procesa, ki se ga učitelji s svojimi pristopi $\mathrm{k}$ poučevanju trudijo spreminjati v t. i. spiralo navzgor. Dodana vrednost naše raziskave je nov pristop $\mathrm{k}$ analizi konteksta, ki ga $\mathrm{v}$ učni proces vnaša fiksna miselnost učencev. $Z$ uporabo kakovostnih mednarodno preverjenih podatkov smo pridobili nova spoznanja o odražanju 
fiksne miselnosti na področju branja in bralne samopodobe ter razlikah med spoloma pri tem. Slabosti analize so korelacijska narava podatkov, zaradi česar ne moremo trditi, da smo zaznali vzročne povezanosti; morda smo zaznali le korelacije, ki jih v ozadju sprožajo drugi, neprepoznani dejavniki. Obenem smo lahko obravnavali le eno starostno obdobje, is let, in torej ostajajo odprta vprašanja, ali bi podobne učinke lahko zaznali tudi v drugih starostnih obdobjih. Kljub temu naši rezultati nakazujejo področja, kjer bi kazalo nadalje odpirati vprašanja in vnašati spremembe. Nadaljnje raziskovanje bi se lahko usmerilo v razširitev modela še z morebitnimi drugimi pomembnimi dejavniki, kot je na primer socialno-ekonomski status, za katerega sicer vemo, da se močno povezuje z dosežki (npr. OECD, 2019b), vendar pa ima lahko tudi lasten vpliv v samopodobi (Watson et al., 2019). Zanimive bi bile tudi mednarodne primerjave.

\section{Sklep}

Nacionalna strategija za razvoj bralne pismenosti za obdobje 2019-2030 (2019) navaja, da bralna pismenost omogoča in spodbuja osebnostni razvoj in socialno vključenost posameznikov in posameznic $\mathrm{v}$ skupnost ter učinkovit gospodarski razvoj trajnostno naravnane družbe (ibid.: str. 4) ter da je proces vseživljenjskega učenja na nacionalni ravni mogoče učinkovito uresničevati le $s$ stalnim razvojem kompetenc bralne pismenosti $\mathrm{v}$ vseh starostnih skupinah prebivalstva (ibid.: str. 5). Izsledki naših analiz omogočajo razumevanje, da je v medsebojni povezanosti dosežkov in samopodobe naloga učiteljev skrb za obe vrsti vzgojnoizobraževalnih rezultatov in da je ob tem, še posebno za šibkejše učence, pomemben kontekst razvojne oziroma fiksne miselnosti.

\section{Literatura}

van Aalderen-Smeets, S. I., in Walma van der Molen, J. H. (2018) Modeling the relation between students' implicit beliefs about their abilities and their educational STEM choices. International Journal of Technology and Design Education 28, str. I-27.

APA - American Psychological Association, Coalition for Psychology in Schools and Education (2015) Top 20 principles from psychology for preK-I2 teaching and learning. Spletna stran: http://www.apa.org/ed/ schools/cpse/top-twenty-principles.pdf, (pridobljeno 31. 5. 2020).

Bejjani, C., DePasque, S., in Tricomi, E. (2019) Intelligence mindset shapes neural learning signals and memory. Biological Psychology 146, I07-715. 
Bettinger, E., Ludvigsen, S., Rege, M., Solli, I. F., in Yeager, D. (2018) Increasing perseverance in math: Evidence from a field experiment in Norway. Journal of Economic Behavior \& Organization I46, str. I-I5.

Bostwick, K. C. P., Martin, A. J., Collie, R. J., in Durksen, T. L. (2019) Growth orientation predicts gains in middle and high school students' mathematics outcomes over time. Contemporary Educational Psychology 58, str. 213-227.

Burnette, J. L., Knouse, L. E., Vavra, D. T., O’Boyle, E., in Brooks, M. A. (2020) Growth mindsets and psychological distress: A meta-analysis. Clinical Psychology Review 77, 101-816.

Costa, A., in Faria, L. (2018) Implicit theories of intelligence and academic achievement: A meta-analytic review. Frontiers in Psychology 9, 829.

Covington, M. V. (1992) Making the grade: A self-worth perspective on motivation and school reform. Cambridge University Press: New York.

DeLuca, C., Coombs, A., in LaPointe-McEwan, D. (2019) Assessment mindset: Exploring the relationship between teacher mindset and approaches to classroom assessment. Studies in Educational Evaluation 6I, str. $159-169$.

Dunning, D. (2005) Self-insight: Roadblocks and detours on the path to knowing thyself. Psychology Press: New York.

Dweck, C. (1986). Motivational processes affecting learning. The American Psychologist, 4I(IO), str. 1040-1048.

Dweck, C. (2007) Mindset: The New Psychology of Success. Ballantine books: New York.

Dweck, C. (2012) Mindsets and human nature: Promoting change in the Middle East, the schoolyard, the racial divide, and willpower. American Psychological Association 67 (8), str. 614-622.

Dweck, C. S., in Yeager, D. S. (2019) Mindsets: A view from two eras. Perspectives on Psychological Science I 4 (3), str. 48I-496.

Dweck, C.S. (2008) Mindsets and math/science achievement. Prepared for the carnegie corporation of New York-Institute for advanced study commission on mathematics and science education. Spletna stran: file://D:/or\%20MyDocs2020\%207jun2o/ E_\%C4\%8Dlanki2020/13\%2oclanki\%2oGrowthMindset\%20 apr20/Dweck2008\%20Mindset_and_math_science_achievement. pdf(pridobljeno 31. 5. 2020).

Ehrlinger, J., Johnson, K., Banner, M., Dunning, D., in Kruger, J. (2008) Why the unskilled are unaware: Further explorations of (absent) 
self-insight among the incompetent. Organizational Behavior and Human Decision Processes 105, str. 98-I2I.

Good, C., Aronson, J., in Inzlicht, M. (2003) Improving adolescents' standardized test performance: An intervention to reduce the effects of stereotype threat. Applied Developmental Psychology 24, str. 645-662.

Good, C., Rattan, A., in Dweck, C. S. (2012) Why do women opt out? Sense of belonging and women's representation in mathematics. Journal of Personality and Social Psychology 102, str. 700-717.

Gunderson, E. A., Gripshover, S. J., Romero, C., Dweck, C. S., GoldinMeadow, S., in Levine, S. C. (2013) Parent praise to I- to 3-year-olds predicts children's motivational frameworks 5 years later. Child development 84 (5), str. 1526-154I.

Haimovitz, K., in Dweck, C. S. (2016) Parents' views of failure predict children's fixed and growth intelligence mind-sets. Psychological Science 27 (6), str. 859-869.

Hwang, NY., Reyes, M., in Eccles, J. S. (2019) Who holds a fixed mindset and whom does it harm in mathematics? Youth and Society 51 (2), str. 247-267.

IEA. (brez datuma) IDB Analyzer. Spletna stran: http://www.iea.nl/data. html (pridobljeno 20. I. 2020).

Kruger, J., in Dunning, D. (1999) Unskilled and unaware of It: How difficulties in recognizing one's own incompetence lead to inflated selfassessments. Journal of Personality and Social Psychology 77 (6), str. II2I-II34 .

Lee, Y., in Seo, E. (2019) Trajectories of implicit theories and their relations to scholastic aptitude: A mediational role of achievement goals. Contemporary Educational Psychology 59, 101800.

Leroy, N., Bressoux, P., Sarrazin, P., in Trouilloud, D. (2007) Impact of teachers' implicit theories and perceived pressures on the establishment of an autonomy supportive climate. European Journal of Psychology of Education XXII (4), str. 529-545.

Levy, S. R., West, T. L., Ramirez, L., in Karafantis, D. M. (2006) The protestant work ethic: A lay theory with dual intergroup implications. Group Processes \& Intergroup Relations 9, str. 95-II5.

Macnamara, B. N., in Rupani, N. S. (2017) The relationship between intelligence and mindset. Intelligence 64, str. 52-59.

Magajna, 1., Pečjak, S., Peklaj, C., Čačinovič Vogrinčič, G., Bregar-Golobič, K., Kavkler, M. V Tancig, S. (ur.). Učne težave v osnovni šoli problemi, 
M. ŠIMENC, S. ŠTRAUS • IMA MISELNOST O NESPREMENLJIVOSTI INTELIGENTNOSTI ...

perspektive, priporočila. I. natis. Zavod Republike Slovenije za šolstvo: Ljubljana.

Marsh, H. W., Abduljabbar, A. S., Parker, P. D., Morin, A. J. S. Abdelfattah, F., Nagengast, B., Moeller, J., in Abu-Hilal, M. M. (2015) The internal/external frame of reference model of self-concept and achievement relations: Age-cohort and cross-cultural differences. American Educational Research Journal 52 (I), str. 168-202.

Marsh, H. W., in Craven, R.G. (2006) Reciprocal effects of self-concept and performance from a multidimensional perspective: Beyond seductive pleasure and unidimensional perspectives. Perspectives on Psychological Science I (2), str. 133-163.

Marsh, H. W., Pekrun, R., Lichtenfeld, S., Guo, J., Arens, A. K., in Murayama, K. (2016) Breaking the double-edged sword of effort/ trying hard: Developmental equilibrium and longitudinal relations among effort, achievement, and academic self-concept. Developmental Psychology 52 (8), str. 1273-1290.

Martin, A. J. (2015) Implicit theories about intelligence and growth (personal best) goals: Exploring reciprocal relationships. British Journal of Educational Psychology 85, str. 207-223.

Mrazek, A. J., Ihm, E. D., Molden, D. C., Mrazek, M. D., Zedelius, C. M., in Schooler, J. W. (2018) Expanding minds: Growth mindsets of selfregulation and the influences on effort and perseverance. Journal of Experimental Social Psychology 79, str. 164-180.

Mullis, I. V. S., Martin, M. O., Foy, P., in Hooper, M. (2016) TIMSS 2015 International Results in Mathematics. Spletna stran: http://timssandpirls.bc.edu/timss2015/international-results/ (pridobljeno I5. 3 . 2020).

Mullis, I. V. S., Martin, M. O., Foy, P., in Hooper, M. (2017) PIRLS 2016 International Results in Reading. Spletna stran: http://timssandpirls. bc.edu/pirls2or6/international-results/ (pridobljeno 15.3.2020).

Nacionalna strategija za razvoj bralne pismenosti za obdobje 2019-203o. (2019) Spletna stran: https://www.gov.si/novice/2020-0I-I5-nacionalna-strategija-za-razvoj-bralne-pismenosti-za-obdobje-2019-2030/ (pridobljeno 31. 5. 2020).

$\mathrm{Ng}$, B. (2018) The neuroscience of growth mindset and intrinsic motivation. Brain sciences 8 (2), 20.

Nuhfer, E., Cogan, C., Fleischer, S., Gaze, E., in Wirth, K. (2016) Random number simulations reveal how random noise affects the measurements and graphical portrayals of self-assessed competency. Numeracy 9 (I). 
Nuhfer, E., Fleischer, S., Cogan, C., Wirth, K., in Gaze, E. (2017) How random noise and a graphical convention subverted behavioral scientists' explanations of self-assessment data: Numeracy underlies better alternatives. Numeracy Iо (I).

OECD. (2019a) PISA 2018 Results (Volume I): What students know and can do. Paris: OECD Publishing.

OECD. (2019b) PISA 2018 Results (Volume II): Where all students can succeed. Paris: OECD Publishing.

OECD. (2019c) PISA 2018 technical report. Spletna stran: https://www. oecd.org/pisa/data/pisa20I8technicalreport/ (pridobljeno 31. 5. 2020).

Park, D., Gunderson, E. A., Tsukayama, E., Levine, S. C., in Beilock, S. L. (2016) Young children's motivational frameworks and math achievement: Relation to teacher-reported instructional practices, but not teacher theory of intelligence. Journal of Educational Psychology 108 (3), str. 300-313.

Rattan, A., Good, C., in Dweck, C. S. (2012) “It's ok - Not everyone can be good at math": Instructors with an entity theory comfort (and demotivate) students. Journal of Experimental Social Psychology 48 (3), str. 73I-737.

Sheldrake, R. (2016) Differential predictors of under-confidence and over-confidence for mathematics and science students in England. Learning and Individual Differences 49, str. 305-313.

Sisk, V. F., Burgoyne, A. P., Sun, J., Butler, J. L., in Macnamara, B. N. (2018) To what extent and under which circumstances are growth mind-sets important to academic achievement? Two meta-analyses. Psychological Science 29(4), str. 549-57I.

Šterman Ivančič, K. (ur.) (2019) PISA 2018 Nacionalno poročilo s primeri nalog iz branja. Pedagoški inštitut: Ljubljana. Spletna stran: https://www.pei.si/wp-content/uploads/2019/12/PISA20I8_ NacionalnoPorocilo.pdf (pridobljeno 31. 5. 2020).

Watson, R. M., Nuhfer, E., Moon, K. N., Fleisher, S., Walter, P., Wirth, K., Cogan, C., Wangeline, A., in Gaze, E. (2019) Paired measures of competence and confidence illuminate impacts of privilege on college students. Numeracy 12 (2): Article 2.

Yan, V. X., Thai, KP., in Bjork, R. A. (2014) Habits and beliefs that guide self-regulated learning: Do they vary with mindset?. Journal of Applied Research in Memory and Cognition 3 (3), str. I40-152.

Yeager, D. S., Hanselman, P., Paunesku, D., Hulleman, C., Dweck, C., Muller, C., ... in Duckworth, A. L. (2018, March I) MANUSCRIPT 
M. ŠIMENC, S. ŠTRAUS - IMA MISELNOST O NESPREMENLJIVOSTI INTELIGENTNOSTI ...

UNDER REVISION: Where and for whom can a brief, scalable mindset intervention improve adolescents' educational trajectories?.

Zhao, Y. (2020) PISA Peculiarities (I): Why doesn't growth mindset work for chinese students? Spletna stran: https://nepc.colorado.edu/blog/pisa-peculiarities (pridobljeno 9. I. 2020). 